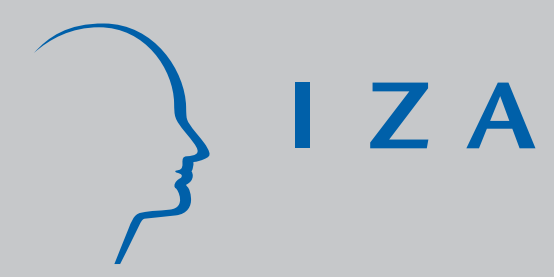

IZA DP No. 1393

Do Markets Favor Women's Human Capital More than Planners?

Daniel Münich

J an Svejnar

Katherine Terrell

November 2004 


\title{
Do Markets Favor Women's Human Capital More than Planners?
}

\author{
Daniel Münich \\ CERGE-El, Prague and CEPR \\ Jan Svejnar \\ WDI, University of Michigan \\ CERGE-EI, CEPR and IZA Bonn \\ Katherine Terrell \\ WDI, University of Michigan, \\ CERGE-EI, CEPR and IZA Bonn
}

Discussion Paper No. 1393

November 2004

\author{
IZA \\ P.O. Box 7240 \\ 53072 Bonn \\ Germany \\ Phone: +49-228-3894-0 \\ Fax: +49-228-3894-180 \\ Email: iza@iza.org
}

Any opinions expressed here are those of the author(s) and not those of the institute. Research disseminated by IZA may include views on policy, but the institute itself takes no institutional policy positions.

The Institute for the Study of Labor (IZA) in Bonn is a local and virtual international research center and a place of communication between science, politics and business. IZA is an independent nonprofit company supported by Deutsche Post World Net. The center is associated with the University of Bonn and offers a stimulating research environment through its research networks, research support, and visitors and doctoral programs. IZA engages in (i) original and internationally competitive research in all fields of labor economics, (ii) development of policy concepts, and (iii) dissemination of research results and concepts to the interested public.

IZA Discussion Papers often represent preliminary work and are circulated to encourage discussion. Citation of such a paper should account for its provisional character. A revised version may be available directly from the author. 
IZA Discussion Paper No. 1393

November 2004

\section{ABSTRACT}

\section{Do Markets Favor Women's Human Capital More than Planners?}

Using micro data on women in the Czech Republic, we compare returns to various measures of human capital at the end of communism (1989), in mid-transition (1996) and in late/posttransition (2002). We show: dramatic increases in returns to education from 1989 to 1996 but no change from 1996 to 2002; no differences in returns to education by state vs. privatelyowned firms; "sheepskin" effects in both regimes, which rise over time and are similar across firm ownership; no difference in returns to education obtained during communism vs. transition; no change in wage-experience profiles over time; and similar increases in returns to education for women and men. In sum, markets pay women and men equally more for their human capital than the planners did; all the adjustment occurred in early transition and was driven by market forces rather than private ownership.

JEL Classification: J24, J31, P20, P31

Keywords: $\quad$ human capital, wages, transition, sheepskin effects, Czech Republic

Corresponding author:

Katherine Terrell

University of Michigan Business School

701 Tappan Street, 7th Floor

Ann Arbor, Ml 48109

USA

Email: terrell@umich.edu 


\section{Introduction ${ }^{1}$}

Whereas a number of studies look at whether the gender wage gap has risen in transition economies (see for example Hunt, 2002; Joliffe, 2002; Jurajda, 2003 and Ogoblin, 1999), we examine the extent to which markets pay women more for their human capital than the planners did, whether the shift to market-based wages affected the return to women's and men's human capital equally, and whether the results vary with firm ownership. ${ }^{2}$ To address these issues, we use data from special surveys that we carried out in the Czech Republic and estimate women's returns to education and experience at the end of the communist period (1989) and six and twelve years after the start of transition (1996 and 2002). We compare our findings to those of an earlier study (Münich, Terrell and Svejnar, 2005) that estimates men’s returns using the same data for 1989 and 1996 and we also estimate men's returns in 2002. This enables us to assess whether markets favored women's human capital over men's or vice versa. Finally we compare our results to those of other studies of men and women's changes in returns to human capital in the transition economies to draw broader conclusions.

In addition to increasing our understanding of gender differentials in the returns to human capital before and during the transition, our study contributes to the literature by examining returns to various measures of human capital. In particular, we examine the returns to actual years of schooling as a measure of education rather than imputed years based on the highest degree obtained. We use the information on actual years of education and highest level attained for each individual to test for the bias created in other studies by using imputed measures of schooling and to measure sheepskin effects (jumps in wages when degrees are received, controlling for years of education). We also test directly whether education gained in the communist versus post-communist periods generates different rates of return during the transition period. Finally, we test whether market forces induce identical wage setting in all firms or whether rates of return on human capital differ across firm ownership. In particular, we compare the returns to human capital in the state sector with those in the private sector. 
We demonstrate that the communist system maintained an extremely low rate of return to education for women, the first six years of the transition resulted in a major increase in the rates of return to a year of education and, surprisingly, the returns remained constant in the second six years of the transition. We show that there was no significant difference in the returns to a year of education between the state sector and private sectors in either 1996 or 2002. With two exceptions (noted below), the same is essentially true for returns to the various levels of education. Hence the major plan-to-market adjustment in rates of return to human capital occurred in the first six years of the transition. A comparison of the 1996 rates of return in the Czech Republic with those of the West European countries (Psacharopoulos, 1994) indicates that they are indeed similar.

With respect to other measures of human capital, we show that the sheepskin effect was prevalent during communism for vocational high school and university graduates. The effect grew stronger between 1989 and 1996 as the size of the coefficients increased significantly for both of these degrees and became significant and grew for the academic high school. Moreover, the 1996 sheepskin effects were replicated in the 2002 data and they were virtually identical across ownership types. We also show that the earlier studies have probably overestimated the rate of return to education by using years of education imputed from the highest degree obtained rather than actual years of schooling as an explanatory variable.

We find that education obtained after the communist period does not have higher returns than education gained during communism. This result holds for both 1996 and 2002, despite the fact that several changes had been made in the education system and more women had the opportunity to study in the 1990s. Our estimates of the effects of experience on earnings indicate that women's wage-experience profile was concave in both regimes and on average did not change from the communist to the mid and late/post transition periods. Finally we show that women and men experienced virtually identical changes in the returns to their education over this period, a pattern that is also found on earlier data in several other transition economies. 
The paper is organized as follows: In Section 2 we describe our data and methodology. Section 3 contains our empirical findings on returns to traditional measures of education in 1989, 1996 and 2002, while in Section 4 we present our tests for sheepskin effects, the potential bias introduced by using imputed vs. actual years of education and differences in the returns to new vs. old human capital. In Section 5 we examine the returns to experience in each of these three years, while in Section 6 we compare our findings on women to our previous findings for men (Münich et al., 2005) and to the findings in the literature for other transition economies. We conclude the paper in Section 7.

\section{Data and Methodology}

We use data from two surveys that employ nearly the same questionnaire and sampling frame. The first survey was administered in December 1996 to 3,157 randomly selected households in all districts of the Czech Republic. The second one was administered in December 2002 to 3,081 households in all districts of the Czech Republic. The second survey is not completely randomly selected as we attempted to follow up on as many households from the 1996 survey as we could. We obtained responses from 721 households (1,125 individuals) that are in both surveys. The remaining households and individuals were selected in such a way as to ensure the final sample was representative in 2002. Comparisons of the major demographic characteristics of the 1996 and 2002 samples with the corresponding populations (1996 and 2002 Labor Force Survey) indicate that the samples are indeed representative. ${ }^{3}$

The questionnaire administered in December 1996 asks for the wage and other characteristics of the jobs held then and also in January 1989, the first month of the last year of the communist regime. ${ }^{4}$ The questionnaire administered in December 2002 asks virtually the same questions about the job held at the time of the survey. Two questions that are important for our survey varied slightly: 1) In 1996, a respondent could include taxes and child benefits in the earnings while in 2002 earnings were reported as net of any tax and transfers. (Hence, we include control variables for the 1989 and 1996 data to make them comparable to the 2002 data.); 2) In 
1996 respondents were asked whether the firm in which they worked was a state owned enterprise (SOE), a privatized SOE or a new (de novo) private firm. In 2002 they were only asked if the firm was privately owned. In order to make this variable comparable over time, we combine the firm size and ownership categories to create a new variable in 2002: large private firms (with more than 50 employees) vs. small private firms (with less than 50 employees). Since in 1996 most of the privatized firms had more than 50 employees and most of the de novo firms had less than 50 employees, these categories are fairly similar. The comparable data permit us to estimate cross-sectional earnings functions at one point in time near the end of communism (January 1989), one point in time in the midst of the transition (December 1996) and one point in late transition (December 2002).

Different types of data have different strengths and weaknesses. A potential weakness of the retrospective (1989) data is the possibility of recall error. In our case, the potential problem is that individuals may not accurately remember their past wages. We expect this error to be relatively small, however, since wages set in the communist grid were clearly defined and did not change much through time, and January 1989 was a memorable period that people could recall quite clearly in $1996 .{ }^{5}$ Moreover, since we use the self-reported wage as a dependent variable rather than as a regressor, we also avoid the usual problem of "errors in variables bias" with respect to the right hand side variables.

In order to obtain estimates of the returns to human capital at the end of communism (1989) and during the transition (1996), we first estimate the following human capital earnings function with our 1989 and 1996 cross-sectional data:

$$
\ln W_{i}=\alpha_{0}+\alpha_{1} E_{i}+\alpha_{2} X_{i}+\alpha_{3} X_{i}^{2}+\alpha_{4} P_{i}+A_{i}^{\prime} \beta+\varepsilon_{i},
$$

where $\ln W_{i}$, the natural logarithm of the hourly earnings of individual $i$, is taken to be a function of her educational attainment $\left(E_{i}\right)$, number of years of potential labor market experience $\left(X_{i}\right)$, a dummy variable for whether the woman worked in Prague $\left(P_{i}\right)$, and a set of ten industry dummy 
variables for the industry location of the individual's job $\left(\boldsymbol{A}_{\boldsymbol{i}}\right){ }^{6}$ The variables $\boldsymbol{A}$ and $P$ control for industry wage effects, compensating differentials, and agglomeration effects of the central city.

In addition to examining the returns to all female workers, we compare the returns to human capital in the state sector (including state-owned enterprises, public administration, health and education), henceforth 'state', and in the private sector. In 1996 we subdivide the private sector into privatized firms and de novo private firms because of the interest in the literature in this distinction in the early part of transition. However, in 2002 we no longer obtain information on whether a firm is a "new private firm" and we divide the private firms into small and large ones, using 50 employees as the dividing line.

An important stylized fact from the human capital literature is that the effect of education on wages often depends on how the education variable $E$ is measured. Unlike Krueger and Pischke (1995), Chase (1998) and Flanagan (1998), who have to impute $E$ from the highest educational degree completed, we are able to use and test the relative merit of three different specifications of $E$ : i) the actual self-reported number of years of education (net of grade repetition), ii) the highest level of attained schooling, and iii) a combination of i) and ii) above.

The "number of years of education" specification yields an estimate of a constant marginal rate of return on an additional year of schooling and reflects the approach advocated by Layard and Psacharopoulos (1974). The "highest level of educational attainment" by type of degree obtained allows the rate of return to vary across types of completed education and reflects the criticism of the assumption of a constant rate of return to each year of education (Heckman, Layne-Farrar and Todd, 1996). ${ }^{7}$ By including both of these variables, we are able to test between the competing specifications and see which one is better supported by the data in the communist and transitional contexts. Moreover, since we have data on actual years of schooling reported by the respondent, rather than years imputed by the researchers from the reported school attainment, we can test the "sheepskin" hypothesis that "wages rise faster with extra years of education when the extra year also conveys a certificate” (Hungerford and Solon, 1987). ${ }^{8}$ 
Our potential labor force experience variable $X$ is calculated in the usual way: the individual's age minus the sum of the individual's years of schooling and basic school enrollment age of six years. However, given the standard practice in the Czech Republic of women taking three years of maternity leave, we also use a second measure where we adjust the women's potential experience measure by subtracting three years for each child the woman gave birth to.

A common concern when estimating earnings functions is self-selection, i.e., the potential for censoring either at the top or the bottom of the wage distribution if some people choose not to work and their earnings are not observable. Heckman's (1974) two-step procedure has been widely used to correct for selectivity bias when estimating women's earnings functions. ${ }^{9}$ However, recently this method has been severely criticized on a number of issues (see for e.g., Nawata, 1993 and Puhani 2000). One concern is that the two-step estimators are too sensitive to distributional assumptions imposed on the error term in both equations. If the error in the selection equation is not normally distributed, the two-step linear formula does not apply and the estimators are biased. Another criticism is that the second-stage earnings equation estimates are often subject to multicollinearity, which has an adverse impact on robustness of the two-step estimator. In particular, multicollinearity becomes a problem if the explanatory variables are highly correlated with the inverse Mills ratio. This is common in applications like ours, where the set of variables in the selection and earning equations overlap significantly and the excluded (identifying) set of variables is not a strong predictor of participation. Given that we do not have in our data set variables that strongly predict participation and not earnings, we do not correct for potential selectivity bias. ${ }^{10}$ Our estimates should hence be interpreted as the returns to human capital, conditional on participation in the labor market.

In appendix Table A.1, we present the 1989, 1996 and 2002 means and standard deviations of the variables that we use in estimating the earnings functions. As may be seen from the tables, we have useable data on 1,642 full-time working women, between the ages of 15 and 60 in 1989, 1,374 in 1996 and 1,104 in 2002. ${ }^{11}$ The average log nominal earnings rose 
substantially over the period, from 7.9 to 8.7 to 9.1 . The average number years of education remained fairly constant at around 12 years and about two-thirds of the working women have attained a vocational or academic high school degree. Over time, the share of women with junior high school education fell while the share with academic high school rose. The average number of years of experience in the labor market rose from 17 under communism to about 20-21 during the transition.

The structure of jobs in the economy changed in ways that are common to most transition economies: the shares of employment in agriculture and manufacturing fell while the shares in commerce (trade) and financial services experienced rapid increases. The structure of jobs by ownership of firms changed dramatically from virtually complete state ownership in 1989 to a small share (25\%) in 1996. We note that there is not much change in the structure of jobs by type of firm ownership between 1996 and 2002, with the caveat that the two private ownership categories are not strictly comparable across the two surveys. The descriptive statistics indicate that the economy seems to have reached a steady-state by 1996 where about one-third of the jobs were in large private firms, one-third in small private firms, and about one-quarter in the public sector (SOE or public administration), with the remainder "not specified by respondents."

\section{Findings on Traditional Estimates of Returns to Education}

In Table 1 we present the most commonly reported estimates of returns to education: returns to a year of education (Panel A) and returns to various levels of educational attainment (Panel B). These estimates come from two separate regressions and control for the variables listed in equation (1). From Table 1 it is clear that markets are paying women considerably more than the planners did for an additional year of education but, interestingly, all the adjustment was made in the first six years of the transition: the returns to a year of schooling rose (significantly) from 3.7 percent in 1989 to 7.1 percent in 1996 but then did not change significantly in 2002, when it is estimated to be 6.8 percent. The 1996 and 2002 rates of return are very similar to 
those reported for all workers for the late 1980s in Great Britain (6.8) and Switzerland (7.9), but somewhat less than the 9.3 percent in the U.S. (Psacharopoulos, 1994). ${ }^{12}$

In Panel B, we find that markets are also paying women significantly more for each level of educational attainment. Again, all of the increase was experienced in the first six years of the transition since almost all of the coefficients for each level of education are not significantly different in 2002 from 1996. The exception is the return to vocational high school education, which fell slightly between 1996 and 2002. As an example of the tremendous gains in the returns on education, in 1989 a university education yielded earnings that were 36.5 log points (or 45\%) higher than the earnings from a junior high school education, but by 1996 and 2002 university graduates were receiving approximately $85-90 \%$ more - nearly double the earnings of the junior high graduates.

Having established that markets pay significantly more for a unit of education than the communists did, the question arises as to whether this is driven by markets in general or only by firms with specific types of ownership. In other words, do we find similar returns across all enterprises, irrespective of ownership type, or is the higher return seen, for example, only in the private sectors and not in the state sector? In Table 2 we present returns to a year and a level of education for women with a job in the state sector or in one of two private sector categories. We find that markets are indeed working throughout the economy in determining returns to education -- there are no significant differences in the returns paid for a year or level of education between any pair of these three ownership types. The one exception is the return to vocational education, for which the state sector pays more relative to privatized firms in 1996 and relative to large private firms in 2002. The second finding from Table 2 is that the returns to either a year or a level of education did not change between 1996 and 2002 for any of three sectors, with the one exception being the falling return to vocational schooling in the small private/de novo firms. 


\section{Non-Traditional Estimates of the Returns to Education}

\subsection{Sheepskin Effects}

Screening theories of education suggest that diplomas serve as a signal of higher productivity and one should therefore expect diplomas (“sheepskins”) to be rewarded in the labor market. The usual test for sheepskin effects is to estimate the difference in wages of individuals with and without a diploma, conditional on the number of years of schooling. Except for Jaeger and Page (1996), the numerous studies that use US data to test for sheepskin effects (e.g., Hungerford and Solon, 1987; Card and Krueger, 1992) are based on data that do not have information on the highest degree attained by an individual. They therefore must impute the level attained from the "usual number of years" it takes to complete a given degree. In contrast, researchers of transition economies usually have only information on the highest degree attained and must impute the number of years of schooling of an individual by using the usual number of years it takes to complete a degree. To the extent that individuals obtain a diploma with more or fewer years of study, estimates of sheepskin effects in the US and returns to a year of education in the transition countries are biased. We have collected information on both the individual's reported years of education (net of any repeated grades) and the highest degree attained. We can thus obtain unbiased estimates of the sheepskin effect and also test for the bias using imputed vs. actual years of schooling. We also show a new way of testing for the sheepskin effect by estimating returns to years of study that lead to a degree and those that do not.

In Table 3 we present the coefficients for a specification that includes years of education (net of grade repetition) and dummy variables for highest degree attained, estimated from the 1989, 1996 and 2002 cross sectional data and controlling for the variables listed in equation (1). We find sheepskin effects were not nearly as prevalent under communism as they are in the market based system as communists only valued vocational high school and university diplomas whereas the markets value all four diplomas. The effects were established already by 1996 and F 
tests on pair-wise differences of the coefficients indicate that the value of these three degrees did not grow significantly between 1996 and 2002.

Examining the sheepskin effect by firm ownership during the transition (Table 4), we find that all three ownership types value degrees and, for the most part, they do not differ in their valuation of degrees within a given year. The exception is the privatized sector's higher valuation of academic high school and university degrees in 1996, which most likely reflects a temporary foreign language premium. (F-tests of all other pair wise comparisons indicate that the differences are not significantly different from zero at the $10 \%$ confidence level.)

\subsection{Imputed vs. Actual Years of Education}

We take advantage of the dual reporting in our data and re-estimate our regressions with the imputed years of education in order to assess the magnitude of the errors-in-variables bias of this commonly used measure. Normally, one would expect the imputed years of education would generate a downward bias that is associated with errors-in-variables. However, the imputed years of education may generate an upward bias because the measure systematically underestimates the number of years of schooling for people that study for additional years without obtaining a degree. The coefficient on imputed years of schooling (the first row of Table 5) is slightly higher than the coefficient on actual years attended (Table 2) in 1989 and 2002, however, the difference is only statistically significant in 2002. The F-test does not allow us to reject the hypothesis that the coefficients on imputed and reported year of education are not statistically different from one another in 1989 and $1996 .^{13}$

We also test the hypothesis that a year of education that leads to a degree has a higher payoff than a year that does not result in a degree. To implement the test, we use our information on the total number of reported years of education and the highest degree obtained, together with the knowledge of the usual number of years needed to obtain a given degree. Using this information, we impute the number of years of education used for (a) obtaining the most advanced degree and (b) additional study not resulting in a degree. In Columns 2, 4 and 6 of 
Table 5, we report the coefficients from a specification that enters these two measures as explanatory variables in regression equation (1). In 1989 and 1996 the coefficients on the additional years of study are significantly different from zero but smaller than the coefficients on the imputed years leading to a degree. In 2002 this coefficient is not significantly different from zero, in part because fewer women had studied beyond a degree in that year.

The results point out that there are higher returns to a year of study that contributes toward a degree. Our results also caution that studies imputing years of education from educational attainment and not controlling for the drop-out or repeater phenomena overestimate the rate of return on education.

\section{3 “New” vs. “Old” Education: Returns to Communist Human Capital in Transition}

Many researchers have hypothesized that human capital (both education and work experience) acquired under communism is less appropriate for a market economy than human capital acquired after the fall of communism. This hypothesis implies that communist human capital should receive a lower rate of return than post-communist human capital during the transition. Some labor economists have also noted that apprenticeship/vocational education in the communist economies was often very narrow and expressed doubt about the value of that particular type of education in post-communist labor markets. To test the hypothesis that the education acquired in the transition has a higher value than the education gained during communism, we have identified for each woman the number of years of education obtained under communism (before 1991) and during the transition (after 1991), entered these variables as separate regressors and tested for differences in the returns to each type of human capital in 1996 and 2002. Our hypothesis was that the differences in the two sets of returns would be greater in 2002 since by this year more changes had been enacted in the education system and more women had time to participate in the "new educational system" relative to the old system. ${ }^{14}$

Counter to these expectations, the estimated coefficients for all workers, presented in columns one and five of Table 6, are actually somewhat lower for "new education” in both years 
(0.071 for old vs. 0.061 for new education in 1996 and 0.070 for old vs. 0.054 for new in 2002). However, the Chi Square test indicates that these coefficients are not significantly different from each other. Further examination of the coefficients on communist and post-communist education for those working in the state or either of the two private sectors (columns 2-4 and 6-8) reveals the same finding: there is no statistically significant difference in the returns to education earned prior to vs. after 1991 in any ownership type. Moreover, these returns have not changed over time -- neither for all women, nor for those in the state sector (the strictly comparable group over time).

\section{Returns to Experience}

We report our findings on the returns to experience in the two regimes in Table 7 , where we present the coefficients and standard errors for all workers for the three years. ${ }^{15}$ In 1996 and 2002 we are able to report two different measures for experience: a) the traditional measure of the number of years since leaving school (Age - no. of years of schooling - 6), which was used in 1989 as well; and b) a measure which reflects the fact that most women take three years of maternity leave when they have a child, i.e., Age - no. of years of schooling $-6-3$ (no. of children), which we could not use in 1989 since we do not know the number of children the women had at that time. We recognize that the second measure is only a rough approximation for the time women took off for maternity leave, perhaps overestimating the time for some women. For example, a woman who had two children two years apart would not necessarily take six years out of the labor force to care for her children.

The interesting finding is that the profiles for the traditional measures of potential experience do not change over time. Over this period a woman with 10 years of experience

earns approximately 0.08 to $0.12 \log$ points (8.3\% to $12.7 \%)$ more than a woman entering the labor market for the first time, while a woman with 20 years of experience earns approximately 0.14 to $0.20 \log$ points $(15.0 \%$ to $22.1 \%)$ more than a woman with no experience. 
The profiles measured with the experience measure adjusted for maternity leave appear steeper than the profile estimated with the traditional measure of experience. This difference in the profile was to be expected given the reduction in the number of years of experience. However, in the final analysis, the F-test indicates that profiles estimated with the two different measures of experience are not significantly different from each other.

Our estimates of the wage-experience profile by categories of firm ownership in Table 8 use only the traditional potential experience measure. The estimates show that there are no marked differences in experience-based wage setting by state firms and de novo/small private firms in either 1996 or 2002. The privatized firms in 1996 and large private firms in 2002 display statistically insignificant coefficients, suggesting that the wage experience profile is horizontal, but the large standard errors of these estimates also do not permit us to reject the hypothesis that the coefficients are not statistically different from those in the other ownership categories.

\section{Comparison to Men’s Returns to Human Capital in Communism vs. Transition}

In evaluating women's returns on human capital, it is useful to compare the evolution of women's returns to those of men during the same period. In an earlier study, Münich, et al. (2005) estimate the coefficients on the years and levels of education for men using 1989 and 1996 data that come from the same survey as the women's data. In carrying out the gender comparison we use the coefficients from the Münich et al. paper and supplement them with estimated coefficients from equation (1) using the new 2002 data on men (shown in Appendix Table A.3). This allows us to calculate differences in the return to men's human capital over the same two periods, 1989-1996 and 1996-2002, for which we calculate differences in the returns to women’s human capital (see Appendix Table A.2). We estimate difference in differences and test whether the female-male differences vary significantly over time (see Table 9). In order to give the results of our study broader significance, we also present in Appendix Tables A.2 and

A.3 the returns to education for women and men, respectively, estimated from earlier studies of transition economies in Central and Eastern Europe and the CIS. In Table 9 we present our 
calculations of the evolution in the difference in female-male returns as reported in these studies of transition economies.

The principal finding from analyzing our Czech data is that one cannot reject the hypothesis that the rates of change of men's and women's returns to a year or level of education are the same, and this finding holds from communism to early-mid transition (period 1) as well as from early-mid to late transition (period 2). As seen in the first six rows of Table 9, like women, men experienced a significant increase in the return to their education (year and levels) in the first period and no significant change in the coefficients in the second period. The gains for men and women appear to have been very similar in the first period.

When we compare our findings with those in the literature, a similar pattern emerges for the relative gains of men and women in Estonia, Hungary, Poland, and Slovenia. In these countries the returns to education (year or level) rose at approximately the same rate for men as for women. In particular, we detect no difference in the 1989-94 evolution women’s and men’s returns at all education levels in Estonia; 1987-1992 estimates in Slovenia (Orazem and Vodopivec, 1997), 1995-98 evolution in Hungary, with the exception of college, where women lose (Joliffe and Campos, 2005), and 1994-2001 evolution in Poland, with the exception of secondary vocational, where women gained (Adamchik and Bedi, 2003). Moreover, although we cannot calculate statistical significance for Brainerd's (2000) estimates for the early transition period, in four countries (the Czech Republic, Poland, the Slovak Republic, and Ukraine) the differences in the estimated coefficients are so small as to imply at most limited economic significance. Only two studies signal divergent evolution of women's and men's returns over time: Chase (1998) for the Czech Republic between 1983 and 1993, and Joliffe and Campos (2004) for Hungary between 1986 and 1995. These studies suggest that women lost relative to men in terms of returns to education in the early part of the transition, although in Hungary the finding only applies to people with vocational, general high school and college and university education. Overall, the pattern that can be reconstructed from the various studies suggests that in terms of returns to education, women held their ground (or perhaps lost in one country) relative 
to men in the early transition, but that they did about as well as men in the later phase of the transition.

\section{Concluding Observations}

Using micro data from the end of the communist period (1989), middle transition (1996) and late/post transition (2002), we find that markets pay women more for their education than the planners did. The result holds for both a year of education and a specific level of educational attainment (degree). Hence, while some have argued that communists were good human capitalists (e.g., Flanagan, 1998), our estimates show that markets provide considerably higher education-related returns than planners although markets maintained the same return to human capital gained from experience in the labor force.

Our findings should not to be interpreted as saying that markets reduced the gap between men's and women's earnings, which was not analyzed in this paper. We note that although the gender earnings gap was reduced in the Czech Republic over this period (from 33\% in 1989 to $25 \%$ in 2002), this could not have been brought about by differences in men's and women's evolution in their returns to education, since we found these differences to be statistically insignificant. Interestingly, we also found that changes in the returns to education were very similar for men and women in several other transition economies. Hence, this could not account for any changes in the gender earnings gap in these countries either.

A remarkable finding of our study is that the major increase in the rate of return to education occurred in the first phase of the transition (1989-96) and no further change is observable in the later phase (1996-2002). Our tests based on men's data confirm an identical pattern and our survey of and tests based on earlier studies from other transition economies suggest that this phenomenon is widespread. Moreover, we find that the major restructuring of the pattern of employment by industry and firm ownership and firm size has also occurred in the first rather than the second phase of the transition. Hence, unlike the lengthy process of adjustments in the capital markets and corporate governance, where one observes substantial 
structural changes into the late 1990s and even early 2000s, the labor market appears to have adjusted to the change of regimes relatively fast. In this respect, the labor market mirrors the evolution of productive efficiency of domestic firms, where one also observes changes in the early but not the late transition period (Sabirianova, Svejnar and Terrell, 2005).

Another important result is that the increase in the returns to education is not brought about by differences in firm ownership. Indeed, we find that the increase in the rate of return is very similar in private and state sectors, indicating that returns to education are set by overall labor market competition rather than segmentation of the market by firm ownership.

Our estimates also contradict the hypothesis that education acquired under communism is less appropriate for a market economy than education obtained during the transition. This suggests that communist education, which was always highly reputed internationally in areas such as mathematics and sciences, constituted good preparation for working in both economic systems and/or that reforms in the educational system during the 1990s were limited in their impact on an individual's performance in the labor market. This is an important area for future research.

We find that in both regimes wages rise faster with extra years of education when the extra year conveys a certificate (the sheepskin effect). The effect is especially detectable in both middle and late/post transition periods and for higher levels of education. In Münich et al. (2005), we find this to be also true for men but the effect is not as strong as for women. The shift to a market system hence appears to be associated with a somewhat greater emphasis on completed education levels (degrees).

In sum, markets pay women and men equally more for their human capital than the planners did; all the adjustment was made in early transition and it was driven by market forces rather than private ownership. 


\section{References}

Adamchik, Vera A. and Arjun S. Bedi (2003) "Gender Pay Differentials during the Transition in Poland,” Economics of Transition, 11 4: 697-726.

Brainerd, Elizabeth (2000) "Women in Transition: Changes in Gender Wage Differentials in Eastern Europe and the Former Soviet Union,” Industrial and Labor Relations Review, 54 1: 138-162.

Card, David, and Alan B. Krueger (1992) "Does School Quality Matter? Returns to Education and the Characteristics of Public Schools in the United States," Journal of Political Economy, 100 1: 1-40.

Chase, Robert S. (1998) "Markets for Communist Human Capital: Returns to Education and Experience in Post-Communist Czech Republic and Slovakia,” Industrial and Labor Relations Review. 51 3: 401-423.

Flanagan, Robert J. (1998) "Were Communists Good Human Capitalists? The Case of the Czech Republic,” Labour Economics, 5 3: 295-312.

Heckman, James (1974) “Sample Selection Bias as a Specification Error” Econometrica, 47 1: 153-161.

Heckman, James, A. Layne-Farrar and P. Todd (1996) "Does Measured School Quality Really Matter? An Examination of the Earnings-quality Relationship,” Brookings Institution Press.

Hungerford, Thomas, and Gary Solon (1987) "Sheepskin Effects in the Returns to Education,” Review Economics and Statistics, 69 1: 175-177.

Hunt, Jennifer (2002) “The Transition in East Germany: When is a Ten-Point Fall in the Gender Wage Gap Bad News?” Journal of Labor Economics, 20 1:148-169.

Jaeger, Dieter A., and M. E. Page (1996) "Degrees Matter: New Evidence on Sheepskin Effects in the Returns to Education,” The Review of Economics and Statistics, 78 4: 733-740.

Joliffe, Dean (2002) "The Gender Wage Gap in Bulgaria: A Semiparametric Estimation of Discrimination,” Journal of Comparative Economics, 30 2: 276-295.

Joliffe, Dean and Nauro F. Campos (2004) "Does market liberalization reduce gender discrimination? Econometric evidence from Hungary, 1986-1998,” Labour Economics, forthcoming.

Jurajda, Stepan (2003) “Gender Wage Gap and Segregation in Enterprises and the Public Sector in Late Transition Countries,” Journal of Comparative Economics, 31 2: 199-222.

Krueger, Alan B., and Jorn-Steffen Pischke (1995) "A Comparative Analysis of East and West German Labor Markets: Before and After Unification,” in Richard B. Freeman and Lawrence F. Katz, Eds. Differences and Changes in Wage Structures, Chicago: The University of Chicago Press.

Layard, Richard and George Psacharopoulos (1974) "The Screening Hypothesis and the Returns to Education,” Journal of Political Economy, 82 5: 985-998. 
MEDIAN (2003) “Retrospective Labour Force Inquiry II: Research Report,” September.

Münich, Daniel, Jan Svejnar and Katherine Terrell (1997) "Final Report to the Czech Ministry of Labor and Social Affairs on the Retrospective Questionnaire on Employment Histories.” unpublished.

, (2005) "Returns to Human Capital under the Communist Wage Grid and During the Transition to a Market Economy,” Review of Economics and Statistics, forthcoming.

Nawata, Kazumitsu (1993) "A Note on the Estimation of Models with Sample Selection Biases," Economics Letters, 42 1: 15-24.

Ogloblin, Constantin G. (1999) "The Gender Earnings Differential in the Russian Transition Economy,” Industrial and Labor Relations Review, 52 4: 602-627.

Orazem, Peter F., and Milan Vodopivec (1997) “Unemployment in Eastern Europe, Value of Human Capital in Transition to Market: Evidence from Slovenia.” European Economic Review, 41 3-5: 893-903.

Psacharopoulos George (1994) "Returns to Investment in Education: A Global Update,” World Development, 22 9: 1325-1343.

Puhani, Patrick A. (2000) “The Heckman Correction for Sample Selection and its Critique,” Journal of Economic Surveys, 14 1: 53-68.

Sabirianova, Klara, Jan Svejnar and Katherine Terrell (2005) "FDI Spillovers and Distance of Firms to the Frontier," forthcoming in the Journal of the European Economic Association Papers and Proceedings. 


\section{Endnotes}

${ }^{1}$ In preparing the paper, the authors were in part supported by grants from the National Science Foundation (Grant No. SES 0111 783), PHARE (Grant No. CZ 9406 01-01-03), by the National Council for East European and Eurasian Studies (Contract No. 812-32) and by the U.S. Agency for International Development (SEGIR EP Contract No. PCE-I-00-00-00014-00, Russia Task order No. 803). The authors would like to thank Orley Ashenfelter, Stepan Jurajda, Jan Kmenta, an anonymous referee and the participants of the CERGE-EI Applied Microeconomics Seminar and the Comparative Economic Development Seminar at the University of Michigan for valuable comments. We are grateful to Ina Ganguli for excellent research assistance.

${ }^{2}$ For those who are curious, we will note that according to our data, the gender wage gap fell over the period that we analyze. In 1989 women earned 33\% less than men (unconditional means) and by 1996 and 2002, the differences were $29 \%$ and $25 \%$, respectively.

${ }^{3}$ See Münich et al. (1997) and MEDIAN (2003) for a description of the survey and sample design as well as the descriptive statistics of the sample relative to the Labor Force Survey (1996) and Microcensus (2002) data.

${ }^{4}$ The January 1989 date was selected as a point in time for which people were likely to remember their labor market characteristics since 1989 was the year of the revolution that overthrew the communist regime.

${ }^{5}$ See Münich et al. (2005) for evidence on the communist wage grid.

${ }^{6}$ The questionnaire asks about monthly nominal earnings and number of hours worked per week. Hence, we have calculated the hourly earnings based on 8.5 hour work-days, which was common in this period. Although Czechs commonly recall their salary as net of payroll and income taxes (since both of these taxes are taken out before they receive their pay) in 1989 and 1996 about 25 percent of the respondents preferred to report their gross rather than net earnings. As a result, we have included a dummy variable to control for this discrepancy in reporting. In addition, in 1989 and 1996 net earnings in some cases include benefits provided by the state, through the employer, for raising children. We have therefore also included a dummy variable in those two years to control for the cases when the reported earnings include child benefits. In 2002 these respondents were explicitly asked to report earnings net of taxes and child benefits.

${ }^{7}$ Our data permit us to estimate a specification with six categorical variables reflecting the highest degree attained: 1) junior high school (mandatory education of 9 years), 2) apprentices in two-three year programs, 3) technical high school graduates and apprentices in four-year programs who received the technical high school diploma, 4) academic high school graduates, and 5) university graduates and above.

${ }^{8}$ The "sheepskin effect" refers to the fact that wages may not increase steadily with years of education within a given level of schooling but may jump up when a degree is received (see also Heckman et al., 1996). Using U.S. data, Hungerford and Solon (1987) find significant discrete jumps in the return to education upon receiving a degree.

${ }^{9}$ Heckman (1974) characterizes the self-selection problem as a special case of the omitted variable problem in OLS regression. His two-step procedure builds on this, by estimating the omitted variable (an inverse Mills ratio) in a first-stage selection model (on all the population) and entering this variable into the earning regression in the second-stage OLS regression (on the working population).

${ }^{10}$ Additional factors played a role in our decision not to estimate the Heckman's two-step procedure: a) we do not see a large change in women's participation rates over the 1993-2002 period in either our data or the Labor Force Survey data (which reports female LFPRs of 52.3 in 1993, 51.8 in 1996, 52.1 in 1999, 
51.3 in 2001 and 50.9 in 2002). Moreover, as we show in the next paragraph, the structure of education of women did not change in our sample. b) We do not have the necessary information on education for women who were out of the labor force in any year and in 1989 we also do not have information on household characteristics, marital status, etc. of the women who out of the labor force.

${ }^{11}$ During the period we analyze, women in the Czech Republic had a very low incidence of part-time work.

12 Psacharopoulos' (1994) estimated returns to education for men and women around the world indicate that women are often found to have higher returns to education than men. This is the case in the Czech Republic where the estimated returns for men (using the same data) were 2.7, 5.8 and 5.7 in 1989, 1996 and 2002, respectively.

${ }^{13}$ The P values for the F tests are 0.39 in 1989, 0.62 for 1996 and 0.01 in 2002.

${ }^{14}$ Few people who obtained education under communism re-entered schools during the transition.

15 These results are based on the regression where education is measured as "actual years of schooling." We also estimated experience coefficients in a regression with education measured as "level of attainment" and found that there was no statistically significant difference in the experience-earnings profiles estimated with years vs. attainment. To save space, we only report one set of experience coefficients. 
Table 1

Estimated Returns to a Year of Education and to a Level of Education for all Women, 1989, 1996 and 2002

\begin{tabular}{lllc}
\hline \multicolumn{1}{c}{ Variable } & $\mathbf{1 9 8 9}$ & $\mathbf{1 9 9 6}$ & $\mathbf{2 0 0 2}$ \\
\hline Panel A: & & & \\
Year of Education & $0.039 * * *$ & $0.0707^{* * *}$ & $0.0679 * * *$ \\
& 0.004 & 0.0045 & 0.00488 \\
\hline Panel B: & \multicolumn{3}{c}{} \\
Level of Attainment (Base = Junior High School) & \\
Apprentices & $0.066^{* *}$ & $0.156^{* * *}$ & $0.124 * * *$ \\
& 0.029 & 0.027 & 0.029 \\
Vocational H.S. (4 years) & $0.197^{* * *}$ & $0.384^{* * *}$ & $0.315 * * *$ \\
& 0.029 & 0.028 & 0.03 \\
Academic H.S. (4 years) & $0.103 * *$ & $0.368^{* * *}$ & $0.359 * * *$ \\
& 0.042 & 0.04 & 0.037 \\
University & $0.365 * * *$ & $0.645 * * *$ & 0.61 \\
& 0.04 & 0.04 & 0.0395 \\
\hline
\end{tabular}

Notes:

${ }^{* * *},{ }^{* *},{ }^{*}$ Denotes statistical significance at the $1 \%, 5 \%, 10 \%$ level, respectively. Standard errors in parentheses.

Coefficients estimated from separate regressions for years vs. levels. All regressions include experience, experience ${ }^{2}$, and dummies controlling for: region of work (Prague) and industry of job (one-digit level). The 1989 and 1996 regressions also include dummies for inclusion of child 
Table 2

Estimated Returns to a Year and a Level of Education by Ownership Type in 1996 and 2002

\begin{tabular}{|c|c|c|c|c|c|c|}
\hline Variable & State & Privatized & DeNovo & State & $\begin{array}{r}2002 \\
\text { Large } \\
\text { Private } \\
\end{array}$ & $\begin{array}{c}\text { Small } \\
\text { Private }\end{array}$ \\
\hline Year of Education & $\begin{array}{c}0.063 * * \\
(0.006) \\
\end{array}$ & $\begin{array}{l}0.072 \text { *** } \\
(0.013)\end{array}$ & $\begin{array}{l}0.081 * * * \\
(0.009)\end{array}$ & $\begin{array}{c}0.068 * * \\
(0.006) \\
\end{array}$ & $\begin{array}{c}0.07 * * \\
(0.011) \\
\end{array}$ & $\begin{array}{l}0.065^{* * *} \\
(0.009) \\
\end{array}$ \\
\hline $\begin{array}{l}\text { Level of Attainment } \\
\text { (Base is Junior High Scho }\end{array}$ & & & & & & \\
\hline Apprentices & $\begin{array}{l}0.196 * * \\
0.057\end{array}$ & $\begin{array}{l}0.08 * \\
0.046\end{array}$ & $\begin{array}{l}0.204 * * * \\
0.047\end{array}$ & $\begin{array}{l}0.206 * * \\
0.048\end{array}$ & $\begin{array}{l}0.066 \\
0.048\end{array}$ & $\begin{array}{l}0.184 * * * \\
0.064\end{array}$ \\
\hline Vocational H.S. (4 years) & $\begin{array}{l}0.457 * * \\
0.049\end{array}$ & $\begin{array}{l}0.32 \text { *** } \\
0.054\end{array}$ & $\begin{array}{c}0.394^{* * *} \\
0.05\end{array}$ & $\begin{array}{l}0.425 * * \\
0.044\end{array}$ & $\begin{array}{l}0.242 * *= \\
0.052\end{array}$ & $\begin{array}{l}0.245 * * * \\
0.069\end{array}$ \\
\hline Academic H.S. (4 years) & $\begin{array}{c}0.352 \text { ** } \\
0.07\end{array}$ & $\begin{array}{l}0.413 * * * \\
0.078\end{array}$ & $\begin{array}{l}0.341 * * * \\
0.066\end{array}$ & $\begin{array}{l}0.388 * * \\
0.051\end{array}$ & $\begin{array}{l}0.297 * * \\
0.07\end{array}$ & $\begin{array}{l}0.369 * * * \\
0.077\end{array}$ \\
\hline University & $\begin{array}{l}0.616 \text { ** } \\
0.055\end{array}$ & $\begin{array}{l}0.801 * * * \\
0.118\end{array}$ & $\begin{array}{l}0.781^{* * *} \\
0.089\end{array}$ & $\begin{array}{l}0.649 * * \\
0.052\end{array}$ & $\begin{array}{l}0.703 * * 2 \\
0.089\end{array}$ & $\begin{array}{l}0.61^{* * *} \\
0.087\end{array}$ \\
\hline
\end{tabular}

Notes:

***, **, * Denotes statistical significance at the 1\%, 5\%, 10\% level. Standard errors in parenthese

Estimates are based on separate regressions for years vs. levels and for each ownership type. All regressions includ the additional variables described in equation (1). 
Table 3

Sheepskin Effects for all Women, 1989, 1996 and 2002

\begin{tabular}{lccc}
\hline \multicolumn{1}{c}{ Variable } & $\mathbf{1 9 8 9}$ & $\mathbf{1 9 9 6}$ & $\mathbf{2 0 0 2}$ \\
\hline & & & \\
Year of Education & 0.006 & $0.024^{* * *}$ & $0.021^{*}$ \\
& $(0.009)$ & $(0.008)^{* *}$ & $(0.011)$ \\
Apprentices & 0.039 & $0.091^{* * *}$ & $0.070^{*}$ \\
& $(0.036)$ & $(0.033)^{* * *}$ & $(0.041)^{* * *}$ \\
Vocational H.S. (4 years) & $0.165^{* * *}$ & $0.286^{* * *}$ & $0.237^{* * *}$ \\
& $(0.046)$ & $(0.044)^{* *}$ & $(0.052)$ \\
Academic H.S. (4 years) & 0.076 & $0.229^{* * *}$ & $0.284^{* * *}$ \\
& $(0.054)$ & $(0.050)^{* *}$ & $(0.055)^{* * *}$ \\
University & $0.320^{* * *}$ & $0.451^{* * *}$ & $0.444^{* * *}$ \\
& $(0.080)$ & $(0.074)$ & $(0.096)$ \\
\hline
\end{tabular}

Notes:

$* * *, * *, *$ Denotes statistical significance at the $1 \%, 5 \%, 10 \%$ level.

Standard errors in parentheses.

Each column represents a separate regression which includes the same control variables as in all regressions. 
Table 4

Sheepskin Effects by Ownership Type, 1996 and 2002

\begin{tabular}{|c|c|c|c|c|c|c|}
\hline \multirow[b]{2}{*}{ Variable } & \multicolumn{3}{|c|}{1996} & \multicolumn{3}{|c|}{2002} \\
\hline & State & Privatized & DeNovo & State & $\begin{array}{c}\text { Large } \\
\text { Private }\end{array}$ & $\begin{array}{c}\text { Small } \\
\text { Private }\end{array}$ \\
\hline \multirow[t]{2}{*}{ Year of Education } & $0.020^{*}$ & -0.012 & $0.037^{* * *}$ & $0.036^{* *}$ & 0.018 & 0.004 \\
\hline & $(0.011)$ & $(0.017)$ & $(0.014)$ & $(0.013)$ & $(0.024)$ & $(0.020)$ \\
\hline \multirow[t]{2}{*}{ Apprentices } & $0.145^{* *}$ & 0.112 * & 0.098 * & $0.118^{* *}$ & 0.016 & 0.074 \\
\hline & $(0.063)$ & $(0.065)$ & $(0.058)$ & $(0.058)$ & $(0.085)$ & $(0.083)$ \\
\hline \multirow[t]{2}{*}{ Vocational H.S. (4 years) } & $0.376^{* * *}$ & $0.367^{* * *}$ & $0.232^{* * *}$ & $0.290^{* *}$ & 0.170 & $0.230^{* *}$ \\
\hline & $(0.068)$ & $(0.085)$ & $(0.083)$ & $(0.069)$ & $(0.108)$ & $(0.104)$ \\
\hline \multirow[t]{2}{*}{ Academic H.S. (4 years) } & $0.278^{* * *}$ & $0.456^{* * *}$ & $0.201^{* *}$ & $0.260^{* *}$ & $0.225^{*}$ & $0.355^{* * *}$ \\
\hline & $(0.081)$ & $(0.094)$ & $(0.087)$ & $(0.072)$ & $(0.121)$ & $(0.106)$ \\
\hline \multirow[t]{2}{*}{ University } & $0.459^{* * *}$ & $0.899^{* * *}$ & $0.470^{* * *}$ & $0.361^{* *}$ & $0.561^{* * *}$ & $0.575^{* * *}$ \\
\hline & $(0.104)$ & $(0.180)$ & $(0.149)$ & $(0.118)$ & $(0.200)$ & $(0.191)$ \\
\hline
\end{tabular}

Notes:

$* * *, * *, *$ Denotes statistical significance at the 1\%, 5\%, 10\% level. Standard errors in parentheses.

Each column represents a separate regression which includes the same control variables as in all regressions. 


\section{Table 5}

Estimated Returns for "Imputed" years of Education and "Additional" Years of Schooling, 1989, 1996 and 2002

\begin{tabular}{|c|c|c|c|c|c|c|}
\hline Variable & \multicolumn{2}{|c|}{1989} & \multicolumn{2}{|c|}{1996} & \multicolumn{2}{|c|}{2002} \\
\hline & (1) & (2) & (3) & (4) & (5) & (6) \\
\hline Imputed Years of Education & $0.044^{* * *}$ & $0.044^{* * *}$ & $0.074^{* * *}$ & $0.074^{\text {*** }}$ & $0.085^{* * *}$ & $0.085^{* * *}$ \\
\hline & $(0.004)$ & $(0.004)$ & $(0.005)$ & $(0.004)$ & $(0.005)$ & $(0.005)$ \\
\hline Additional Years & - & $\begin{array}{c}0.025^{* *} \\
(0.011)\end{array}$ & & $\begin{array}{c}0.026 \\
(0.011)\end{array}$ & - & $\begin{array}{l}0.013 \\
(0.011)\end{array}$ \\
\hline
\end{tabular}

Notes:

$* * *, * *, *$ Denotes statistical significance at the 1\%,5\%, 10\% level. Standard errors in parentheses.

"Imputed Years" denote the number of years of education imputed from the individual's highest level of educational attainment and the usual number of years it takes to attain that level/degree.

"Additional Years" denote the number of years above the highest level of attainment, which do not lead to a degree.

Each column represents a separate regression which includes the same control variables as in all regressions. 
Table 6

Returns to a Communist vs. New Education (Years) in 1996 and 2002

\begin{tabular}{|c|c|c|c|c|c|c|c|c|}
\hline \multirow[b]{2}{*}{ Years of Education: } & \multicolumn{4}{|c|}{1996} & \multicolumn{4}{|c|}{2002} \\
\hline & All & State & Privatized & DeNovo & All & State & $\begin{array}{c}\text { Large } \\
\text { Private }\end{array}$ & $\begin{array}{c}\text { Small } \\
\text { Private }\end{array}$ \\
\hline & (1) & (2) & (3) & (4) & (5) & (6) & (7) & (8) \\
\hline \multirow[t]{2}{*}{ Years of Education before 1991} & $0.071^{* * *}$ & $0.064^{* * *}$ & $0.074^{* * *}$ & $0.081^{* * *}$ & $0.070^{* * *}$ & $0.069^{* * *}$ & $0.071^{* * *}$ & $0.068^{* * *}$ \\
\hline & $(0.005)$ & $(0.006)$ & $(0.013)$ & $(0.009)$ & $(0.005)$ & $(0.006)$ & $(0.001)$ & (0.009) \\
\hline \multirow[t]{2}{*}{ Years of Education after 1991} & 0.061 & $0.050^{* * *}$ & 0.030 & $0.088^{* * *}$ & $0.054^{* * *}$ & $0.050^{* * *}$ & $0.060^{* * *}$ & $0.054^{* * *}$ \\
\hline & $(0.010)$ & $(0.014)$ & $(0.027)$ & $(0.020)$ & $(0.009)$ & $(0.011)$ & $(0.017)$ & $(0.016)$ \\
\hline
\end{tabular}

Notes:

$* * *, * *, *$ Denotes statistical significance at the 1\%, 5\%, 10\% level. Standard errors in parentheses.

Each column represents a separate regression which includes the same control variables as in all regressions. 


\section{Table 7}

Returns to a Year of Labor Market Experience (Two Measures)

\begin{tabular}{lccc|cc}
\hline & $\mathbf{1 9 8 9}$ & $\mathbf{1 9 9 6}^{\mathbf{a}}$ & $\mathbf{2 0 0 2}^{\mathbf{a}}$ & $\mathbf{1 9 9 6}^{\mathbf{b}}$ & $\mathbf{2 0 0 2}^{\mathbf{b}}$ \\
\hline \multirow{2}{*}{ Experience } & $0.014^{* * *}$ & $0.009^{*}$ & $0.011^{* * *}$ & $0.013^{* * *}$ & $0.016^{* * *}$ \\
& $(0.003)$ & $(0.005)$ & $(0.003)$ & $(0.003)$ & $(0.004)$ \\
Experience $^{2}$ & $-0.0002^{* *}$ & -0.0001 & $-0.0002^{* * *}$ & $-0.0002^{* *}$ & $-0.0004^{* * *}$ \\
& $(0.0001)$ & $(0.0001)$ & $(0.0001)$ & $(0.0001)$ & $(0.0001)$ \\
\hline
\end{tabular}

Notes:

$10 \%$ level. Standard errors in parentheses.

${ }^{a}$ Experience is measured as: Age - years of schooling - 6

${ }^{b}$ Experience is measured as: Age - years of schooling - $6-3^{*}$ (number of children)

Each column represents a separate regression which includes the same control variables as in all regressions, and years of education. 
Table 8

Returns to a Year of Labor Market Experience by Ownership Type, 1996 and $2002^{\mathrm{a}}$

\begin{tabular}{|c|c|c|c|c|c|c|}
\hline & \multicolumn{3}{|c|}{1996} & \multicolumn{3}{|c|}{2002} \\
\hline & State & Privatized & DeNovo & State & $\begin{array}{c}\text { Large } \\
\text { Private } \\
\end{array}$ & $\begin{array}{c}\text { Small } \\
\text { Private }\end{array}$ \\
\hline Experience & $\begin{array}{c}0.009^{*} \\
(0.005)\end{array}$ & $\begin{array}{r}0.010 \\
(0.007)\end{array}$ & $\begin{array}{r}0.011 \\
(0.005)\end{array}$ & $\begin{array}{l}0.017^{* * *} \\
(0.004)\end{array}$ & $\begin{array}{r}0.002 \\
(0.005)\end{array}$ & $\begin{array}{c}0.012^{*} \\
(0.005)\end{array}$ \\
\hline Experience 2 & $\begin{array}{l}-0.0004^{* * *} \\
(0.0001)\end{array}$ & $\begin{array}{r}-0.0001 \\
(0.0002)\end{array}$ & $\begin{array}{r}-0.0002 \\
(0.0002)\end{array}$ & $\begin{array}{l}-0.0003^{* * *} \\
(0.0001)\end{array}$ & $\begin{array}{c}-0.0001 \\
(0.0001)\end{array}$ & $\begin{array}{l}-0.0003^{* * *} \\
(0.0001)\end{array}$ \\
\hline
\end{tabular}

Notes:

$* * *, * *, *$ Denotes statistical significance at the $1 \%, 5 \%, 10 \%$ level. Standard errors in parentheses.

Each column represents a separate regression which includes the same control variables as in all regressior and years of education.

${ }^{a}$ Experience is measured as: Age - years of schooling - 6 . 
Table 9

Empirical Findings on Changes in Women's and Men's Returns to Education

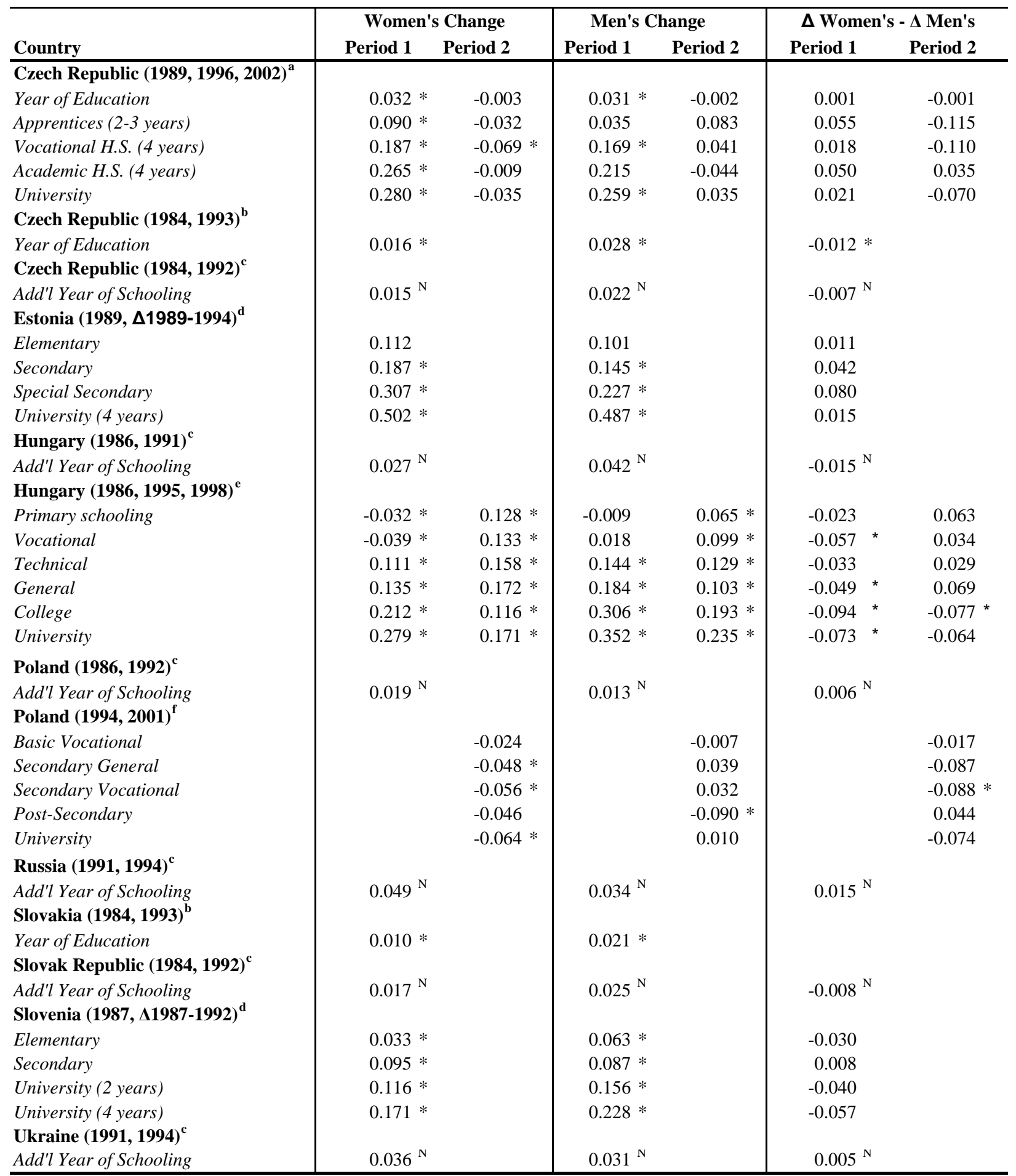

Notes: * Denotes significance at the $10 \%$ level; ${ }^{\mathrm{a}}$ Our results; ${ }^{\mathrm{b}}$ Chase (1998); ${ }^{\mathrm{c}}$ Brainerd (2000); ${ }^{\mathrm{d}}$ Orazem and Vodopivec (2000);

${ }^{\mathrm{e}}$ Jolliffe and Campos (2004); ${ }^{\mathrm{f}}$ Adamchik and Bedi (2003); ${ }^{\mathrm{N}}$ Not able to test for significance.

See Tables A.2 and A.3 in the Appendix for the actual coefficients for each year. 
Table A.1

Means and Standard Deviation of Variables for Earnings Regressions

\begin{tabular}{|c|c|c|c|c|c|c|}
\hline & \multicolumn{2}{|c|}{1989} & \multicolumn{2}{|c|}{1996} & \multicolumn{2}{|c|}{2002} \\
\hline & mean & std. dev. & mean & std. dev. & mean & std. dev. \\
\hline Women's Log of earnings & 7.90 & 0.37 & 8.68 & 0.37 & 9.13 & 0.33 \\
\hline Men's Log of earnings & 8.23 & 0.39 & 8.96 & 0.40 & 9.38 & 0.35 \\
\hline Experience (years) & 16.83 & 9.80 & 20.68 & 10.79 & 19.78 & 11.35 \\
\hline Experience $^{2}$ & 379.41 & 343.56 & 543.86 & 435.64 & 519.98 & 463.92 \\
\hline Education in years & 12.17 & 2.32 & 12.34 & 2.25 & 12.49 & 1.97 \\
\hline \multicolumn{7}{|l|}{ Level of Education: } \\
\hline Junior High School (reference) & 0.145 & 0.352 & 0.111 & 0.315 & 0.077 & 0.267 \\
\hline Apprentices w/2-3 years & 0.375 & 0.484 & 0.365 & 0.482 & 0.363 & 0.481 \\
\hline Vocational H.S. w/4 years & 0.338 & 0.473 & 0.365 & 0.482 & 0.387 & 0.487 \\
\hline Academic H.S. w/4 years & 0.058 & 0.234 & 0.060 & 0.238 & 0.087 & 0.283 \\
\hline University & 0.084 & 0.278 & 0.099 & 0.299 & 0.085 & 0.278 \\
\hline Other variables & & & 1.000 & & & \\
\hline Prague & 0.109 & 0.312 & 0.112 & 0.316 & 0.152 & 0.359 \\
\hline Child benefits included & 0.117 & 0.321 & 0.071 & 0.257 & - & - \\
\hline Gross earnings reported & 0.261 & 0.439 & 0.255 & 0.436 & - & - \\
\hline \multicolumn{7}{|l|}{ Industry: } \\
\hline Agriculture & 0.071 & - & 0.040 & - & 0.030 & - \\
\hline Mining \& Quarrying & 0.026 & 0.160 & 0.015 & 0.123 & 0.014 & 0.120 \\
\hline Construction & 0.026 & 0.158 & 0.025 & 0.155 & 0.019 & 0.137 \\
\hline Commerce (Wholesale and Retail) & 0.174 & 0.379 & 0.211 & 0.408 & 0.303 & 0.460 \\
\hline Manufacturing-Food, Textile, & 0.273 & 0.446 & 0.245 & 0.430 & 0.193 & 0.395 \\
\hline Manufacturing-Machinery & 0.056 & 0.230 & 0.048 & 0.214 & 0.022 & 0.146 \\
\hline Finance, Insurance, Renting \& Real Estate & 0.017 & 0.130 & 0.052 & 0.221 & 0.038 & 0.191 \\
\hline Transport, Telecommunications & 0.056 & 0.230 & 0.063 & 0.242 & 0.059 & 0.236 \\
\hline Public Administration + Education + Health & 0.290 & 0.454 & 0.293 & 0.455 & 0.321 & 0.467 \\
\hline Unknown & 0.011 & 0.104 & 0.009 & 0.093 & 0.002 & 0.043 \\
\hline \multicolumn{7}{|l|}{ Ownership: } \\
\hline Privatized (96) Large Private (02) & - & - & 0.370 & 0.483 & 0.341 & 0.474 \\
\hline SOE \& Public Administration & - & - & 0.251 & 0.434 & 0.292 & 0.455 \\
\hline De Novo Private (96) Small Private (02) & - & - & 0.316 & 0.465 & 0.341 & 0.474 \\
\hline Other \& not known & - & - & 0.079 & 0.270 & 0.026 & 0.160 \\
\hline No. of Obs. & \multicolumn{2}{|c|}{1642} & \multicolumn{2}{|c|}{1374} & \multicolumn{2}{|c|}{1104} \\
\hline
\end{tabular}


Table A2

Empirical Findings on Women's Returns to Education

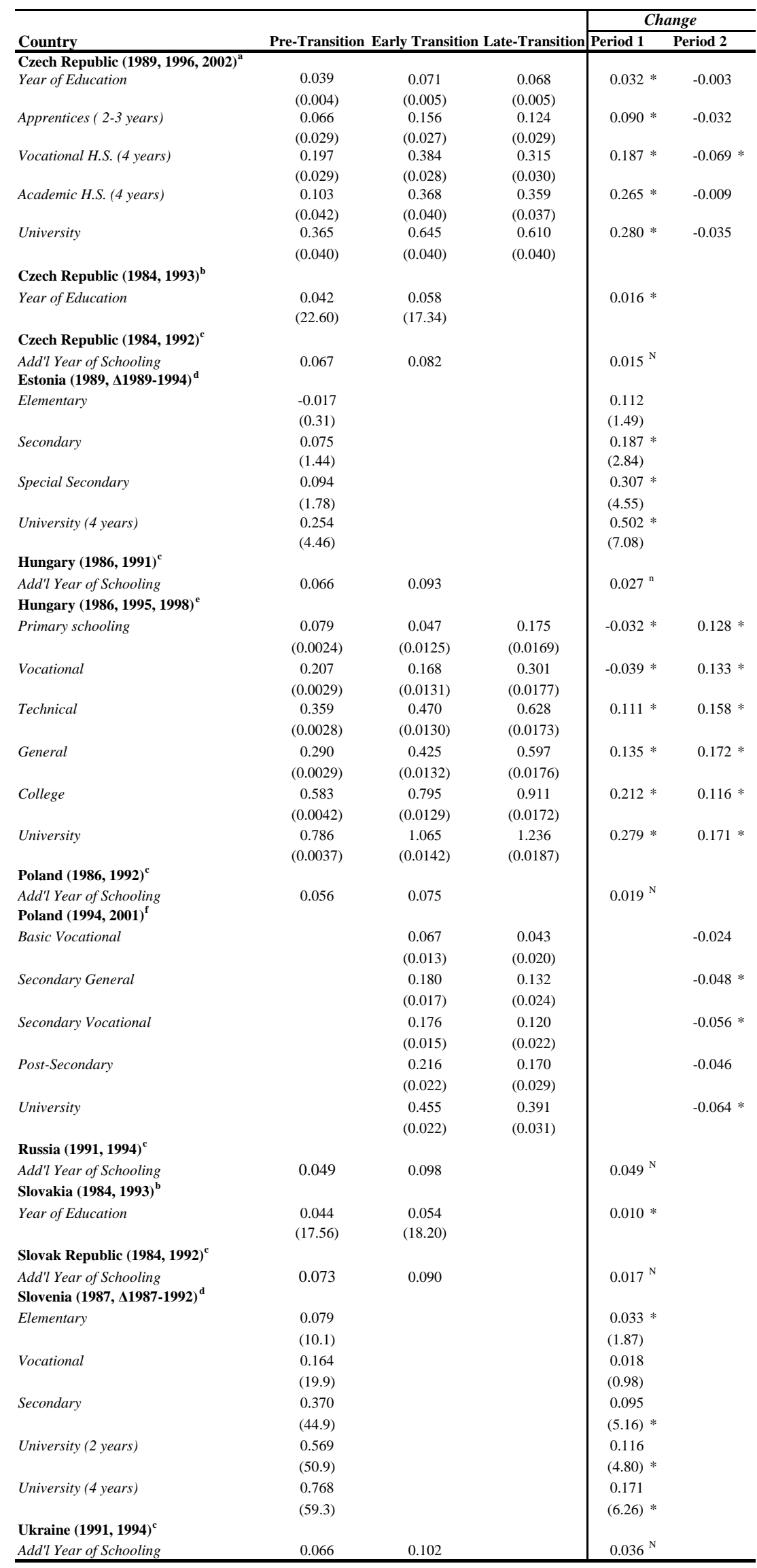

Notes: * Denotes significance at the $10 \%$ level; ${ }^{\mathrm{a} O u r}$ results; ${ }^{\mathrm{b}} \mathrm{Chase}(1998)$; T-Statistics are in parentheses; ${ }^{\mathrm{c}}$ Brainerd (2000); ${ }^{\mathrm{d}}$ Orazem and Vodopivec (2000); ${ }^{\mathrm{J}}$ Jolliffe and Campos (2004); ${ }^{\mathrm{f}}$ Adamchik and Bedi (2003);

${ }^{\mathrm{N}}$ Not able to test for significance. 
Table A.3

Empirical Findings on Men's Returns to Education

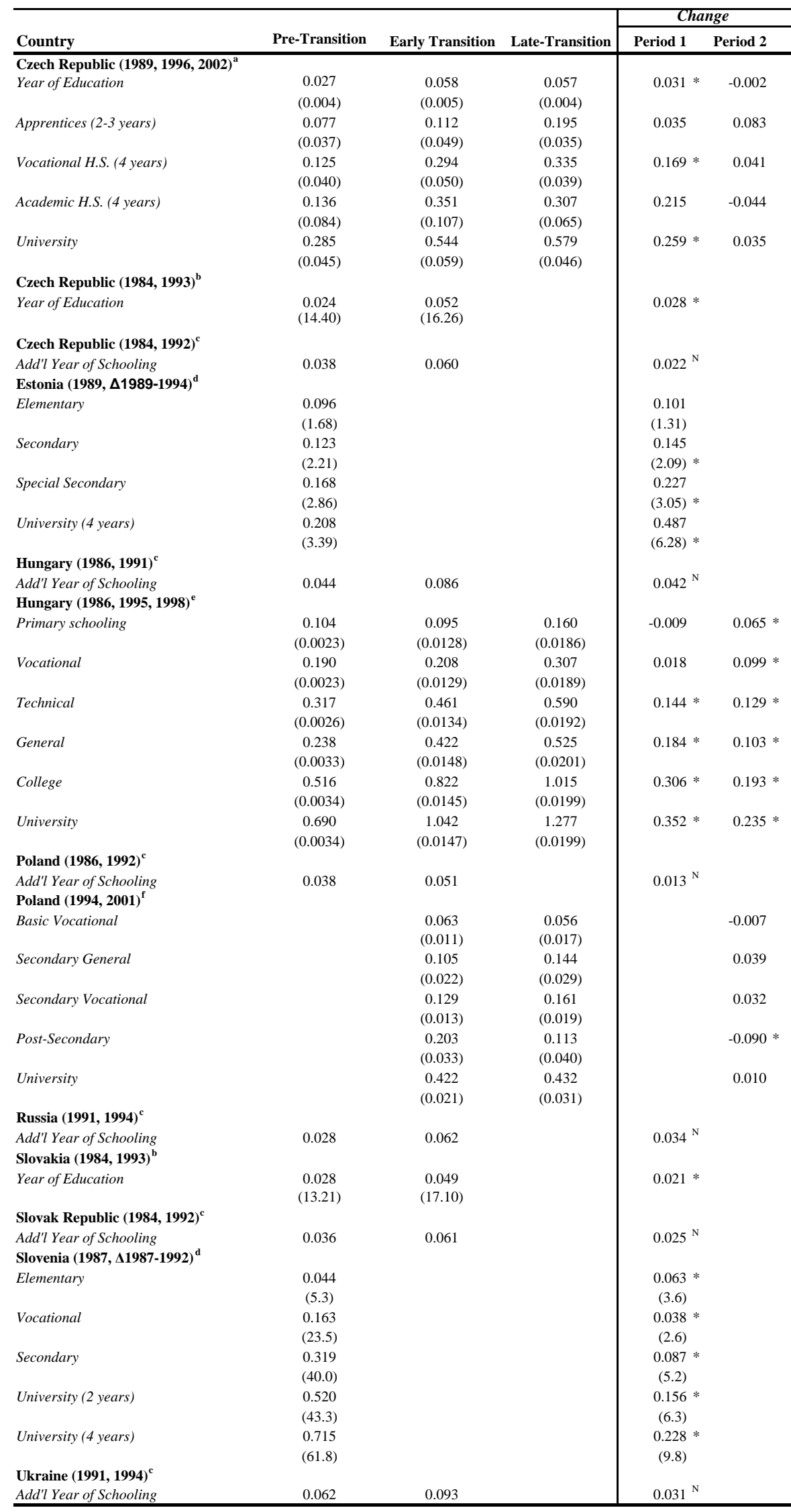

Notes: * Denotes significance at the $10 \%$ level; ${ }^{\mathrm{a} O u r}$ results; ${ }^{\mathrm{D}}$ Chase (1998); T-Statistics are in parentheses; ${ }^{\mathrm{C}}$ Brainerd (2000); ${ }^{\mathrm{d} O r a z e m}$ and Vodopivec (2000); ${ }^{\mathrm{e}}$ Jolliffe and Campos (2004); ${ }^{\mathrm{f}}$ Adamchik and Bedi (2003); ${ }^{\mathrm{N}}$ Not able to test for significance. 